ISSN 2709-3662 (Print)

ISSN 2709-3670 Online)

https://doi.org/10.52587/JAF010102

Journal of Agriculture and Food

2021, Volume 2, No.1, pp. 1-10

\title{
Technical Efficiency Analysis of Wheat Crop in Arid Region of Punjab, Pakistan
}

\author{
Muhammad Fahad Irfan ${ }^{1}$ iD , Kaif Matloob ${ }^{1}$, Muhammad Umer Afzal $^{1}$ iD, \\ Irfan Ahmad Baig ${ }^{2}$
}

\begin{abstract}
The present study aim to estimate the possible effects of credit on production of wheat crop in district Chakwal, Pakistan. The research was based on primary data gathered from 120 farmers, selected by using random sampling technique belonging to two tehsils i.e. Talagang and Chakwal. SFA (Stochastic Frontier Analysis) model was adapted to analyze the data and the results show the mean technical efficiency of the wheat crop was $88 \%$ for borrowers and $76 \%$ for non-borrowers. The results proposed that the technical efficiency of wheat growers can be increased by increasing loan disbursement in the area.
\end{abstract}

Keywords: Wheat, , Stochastic Frontier Analysis, Credit, Efficiency, Arid, Pakistan

Article History:

Received: $31^{\text {th }}$ January, 2021; Revised: $14^{\text {th }}$ May2021; Accepted: $21^{\text {th }}$ May, 2021

${ }^{1}$ Department of Economics and Agriculture Economics, PMAS-Arid Agriculture University Rawalpindi; ${ }^{2}$ Department of Agribusiness and Applied Economics, MNS-University of Agriculture, Multan. Corresponding author's email: fahadirfan1@gmail.com 


\section{Introduction}

Pakistan is listed among 36 countries facing food crisis. Rising global food prices is major concern in all developing countries, which lead to inflation and twice the number of the poor are forced to remain hungry. Agriculture remains the priority sector that generates about $18.5 \%$ of GDP in the country and provides jobs for $38.5 \%$ of its workforce (Government of Pakistan, 2019). More importantly, approximately two third rural population was dependent on agriculture for their livelihood (Government of Pakistan, 2017). Decline in agricultural land, increasing demand for water resources, resource degradation and large-scale inadequacy of the infrastructure are of major concerns of the agricultural sector in Pakistan.

In this era of science and technology, efforts in the field of research are continuously introducing new agricultural technologies helpful in increasing the technical efficiency of the farmers (Bhattacharyya et al., 1997). Growth in the agricultural productivity is revolving around appropriate use of inputs, modern technology and technical efficiency (Croppenstedt et al., 2003; Iqbal et al., 2003; Odoemenem \& Obinne, 2010). The studies on technical efficiency in field crop is of vital importance to find out the possible factors responsible for the efficiency or inefficiency in crop production system which may help the policy makers and planners to frame new policies to overcome the factors responsible for low efficiency or to increase efficiency (Ahmad et al., 2018). The technical efficiency of wheat growers have been studied in various parts of the world, for instance in Afghanistan mean technical efficiency of wheat growers was 0.67 (calculated through ) (Tavva et al., 2017), 0.71(Data envelopment analysis) and 0.51 (Randomized Frontier Function) in Urmia county (Khodaverdizadeh et al., 2019). Technical efficiency varied and dependent upon the factors such as irrigation, credit facility, education level of grower, farm machinery, presence of seed of improved cultivars and intensive labor hired for crop production (Iráizoz et al., 2003; Bozoglu \& Ceyhan, 2007; Mamo et al., 2018). Similarly, the credit facility has made it possible for farmers to employ modern cropping technologies (Khai \& Yabe, 2011).

Agricultural credit is the monetary support that small farmers can get to raise their standard of living by purchasing the technology of crop production (Eswaran \& Kotwal, 1990). These include the use of improved seed varieties, increased use of fertilizers and measures to protect plants, distribution from the lack of irrigation water through tube wells and mechanical growing, harvesting and threshing, etc.

In this modern era, agricultural credit has become a dire need to ensure higher crop productivity, especially in developing countries. Generally the agricultural credits are of three types i.e. long, medium and short term loans depending upon the purpose for which loans are extended (Rosenzweig \& Wolpin, 1993). The increasing prices of key inputs such as fertilizer, quality seeds, pesticides and irrigation have reported an increasing trend in credit requirements. The type of crop grown by the farmer and its associated expenses for cultivation harvesting and financial status of the farmers determines the trend of agricultural credits among farming community. Short-term credit is used to bear the expenses of crop production, intermediate-term credit is extended to employ modern technology and purchasing of implements. Whereas long-term credits are utilized to buy the arable land, or to construct a shed for livestock. The farm efficiency was reported to be affected by financial base of farmer as the debts extended for short duration are 
negatively correlated with technical efficiency however intermediate debts are found to increase the efficiency of farms (Lambert \& Bayda, 2005).

The aim of current study is to highlight the need and efficient use of credit facility in arid zone of Punjab, province of Pakistan. Study was conducted in Chakwal district, where majority of farming community is poor and uneducated.

Present study was designed to focus the agricultural credit need and the productive use of the facility in arid areas of Punjab. For this purpose Chakwal district was chosen. The time taking process for borrowing agricultural loans, mostly offers hindrances to overwhelming majority of illiterate and needy farmers. It is evident that major portion of farming community is not financially strong enough to afford costly inputs necessary for better crops yield, for this farmers need credit facility without any complex loan extending procedure. The current study has been designed to test the impact of agriculture credit on farm productivity. Given study was undertaken to correlate the efficiency scores of both borrower and non-borrower farmers in study area and to suggest policy implications in accordance with outcomes.

\section{Materials and Methods}

The current study was based on primary information about credit taken for agriculture, gathered from borrowers and non-borrower farmer, with the help of a well-built and pre tested questionnaire. Data was collected from randomly selected farmers in district Chakwal, two tehsils Chakwal and Talagang. Chosen tehsils were selected from district because of their higher crop production in the district. These two tehsils produce 60-70 percent of the total district agriculture production. After tehsils selection, one union council was chosen from each tehsils. Sixty farmers were selected from each union council. Among these sixty farmers half of them were borrowers and half were nonborrowers. List of the loan borrowers of these villages was obtained from ZTBL and other commercial Banks operating in the tehsils. The overall sampling framework, which utilized for data collection was multistage purposive random sampling during fiscal year 2012-2013. Random sampling was done from prepared farmer's lists (Fig. 1).

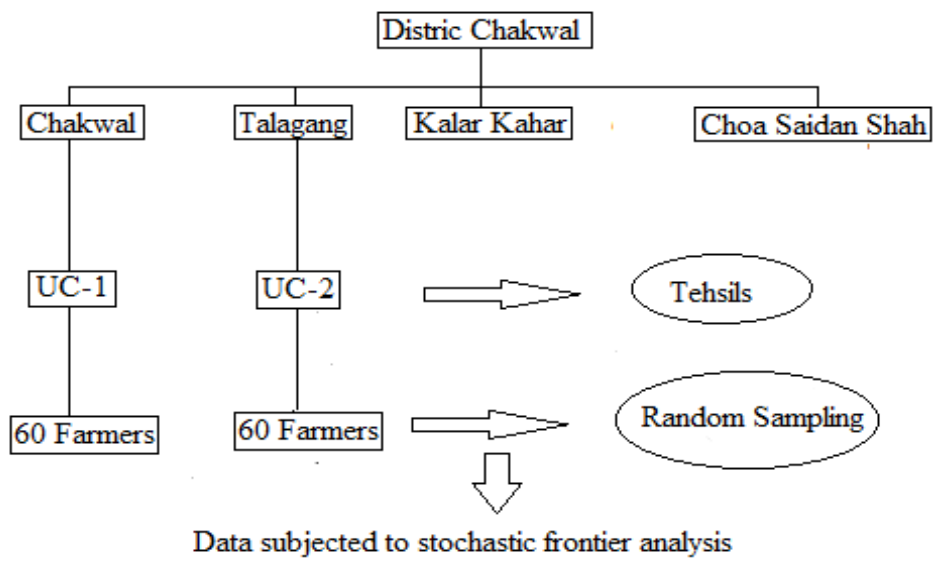

Figure 1. Layout plan of data collection 
Stochastic frontier analysis (SFA) is a modified approach for estimation of productive efficiency. SFA is a method of economic modeling. It has its starting point in the stochastic production frontier models simultaneously introduced by Aigner, Lovell and Schmidt (1977) and Meeusen \&Van den Broeck (1977). In SFA, a specified functional form was used for efficiency estimation and error terms were described for inefficiency measurement (Fare et al., 1985). A firm is said to be technical inefficient if it cannot manage to continue production on the production frontier, or in other words efficiency is obtained if maximum output is produced by minimum use of inputs.

The stochastic production frontier method (Coelli, 1996; Coelli et al., 2005) uses a regression model having the general form: $\quad \ln \mathbf{y}_{\mathbf{i}}=\boldsymbol{\alpha}_{\mathbf{0}}+\boldsymbol{\alpha} \boldsymbol{\Sigma} \ln \mathbf{x}_{\mathbf{i}}+\mathbf{v}_{\mathbf{i}}-\boldsymbol{\mu}_{\mathbf{i}}$

$$
\begin{aligned}
& \mathrm{y}_{\mathrm{i}}=\text { Production of each farmer } i \\
& \mathrm{~V}_{\mathrm{i}}=\text { Randomly distributed error term } \\
& \mu_{\mathrm{i}}=\text { Inefficiency error term } \\
& \mathrm{x}_{\mathrm{i}}=\text { Vector of inputs used }
\end{aligned}
$$

The following two groups of variables were employed.

Variables for frontier production function (Wheat)

Variables for technical inefficiency model (Wheat)

Variables for Stochastic frontier production function (Wheat)

$$
\text { O.P }=f(C, O f, F, S d, W, D s, D t, M)
$$

Table 1. Variables used for Model (i)

O.P Wheat production (Mounds acre ${ }^{-1}$ )

C Land Cultivation time ( $\mathrm{hr}$ acre $\left.^{-1}\right)$

$\boldsymbol{O}_{f} \quad$ Amount of Organic fertilizer (tons acre ${ }^{-1}$ )

F Amount of Synthetic fertilizer $\left(\mathrm{kg} \mathrm{acre}^{-1}\right)$

S $_{\mathbf{d}} \quad$ Seed rate $(\mathrm{kg} / \mathrm{acre})$

W Expenditure on quality weedicides (PKR acre $\left.{ }^{-1}\right)$

Ds Dummy for Sowing method (1 for Drill sowing and 0 for otherwise)

Dt Dummy for Tehsils (1 for tehsil Talagang and 0 for otherwise)

M Dummy for Seed source (1 for Market and 0 for otherwise)

Variables for technical inefficiency function (Wheat) $O . P=f(A, E d, E x, L, C s, S I$, $D t, D c) \ldots($ ii)

Table 2. Variables used for Model (ii)

A Farmer's age (Years)

$\mathbf{E}_{\mathbf{D}}$ Education level of farmer (Schooling years)

Ex Farming Experience (Years)

L Land under cultivation (acres)

Cs Dummy variable for Chemical sprays used (1 for Yes and 0 for otherwise)

SI Dummy variable for any other Household income source ( 1 for Yes and 0 for otherwise)

D Dummy variable for Tehsils (1 for tehsil Talagang and 0 for otherwise)

DC Dummy variable for credit (1 for Borrowers and 0 for Non-borrowers) 


\section{Results}

Current study was based upon cross-sectional data gathered from 120 farmers involved in agricultural practices in Talagang and Chakwal, the most productive tehsils of District Chakwal, these two tehsils were chosen by using purposive sampling technique. Moreover to calculate the efficiency of farms in study area Stochastic Frontier Analysis (SFA) was employed. Results depicted the mean age of the credit borrower and non-borrower farmers were 48.4 and 50.7 years with average education of 7.1 and 8.3 years of formal schooling and mean crop farming experience of 12.5 and 22.5 years respectively. Estimates of maximum likelihood for efficiency and inefficiency effect models are shown in Table 3 and Table 4 respectively. Study results showed that almost all variables contribute positively, P-values of the production function sorted out four variables significant statistically at $1,5,10 \& 15 \%$. The coefficient of land cultivation time variable showed that, there will be $4.925 \mathrm{~kg}$ increase in wheat produce if land cultivation time is increased by 1 percent.

Coefficient value of weedicide cost depicted that there will be $0.5 \mathrm{~kg}$ increase in wheat production if expenditure for this head is increased by 1 percent. Similarly elasticity of organic fertilizer value showed there will be $0.13 \mathrm{~kg}$ increase in wheat produce if amount of organic fertilizer is increased by 1 percent. The recommended rate of wheat seed sown for wheat cultivation, appropriate as well as timely applications of fertilizer doses are important for better yield. Synthetic fertilizer elasticity results indicated that one percent increase in synthetic fertilizer applied to wheat crop is expected to increase $4.988 \mathrm{~kg}$ of final produce. The value of seed rate depicted that there will be $6.048 \mathrm{~kg}$ increase in wheat produce if amount of seed sown is increased by 1 percent.

Table 3. Maximum Likelihood Estimates (Efficiency Variables)

\begin{tabular}{|l|c|c|}
\hline Variables & Coefficient & P-values \\
\hline Constant & 2.2896 & 0.00003755 \\
\hline Land Cultivation time (hr/acre)) & 0.1231 & 0.10731094 \\
\hline Amount of Organic fertilizer (tons/acre) & 0.0032 & 0.27154836 \\
\hline Amount of Synthetic fertilizer (kg/acre) & $0.1247 *$ & 0.02432646 \\
\hline Seed rate (kg /acre) & $0.1512^{*}$ & 0.01174169 \\
\hline Expenditure on quality weedicides (PKR/acre) & $0.01105^{*}$ & 0.01838841 \\
\hline Dummy for Sowing method & -0.0046 & 0.48144404 \\
\hline Dummy for Tehsil & -0.0051 & 0.48556678 \\
\hline Dummy for Seed source & 0.1781 & 0.02122919 \\
\hline Sigma-square ( $\sum^{\mathbf{2}}$ ) & 0.2206 & 0.022177 \\
\hline Gamma $(\boldsymbol{\gamma})$ & 0.9606 & $<0.0000$ \\
\hline Log Likelihood Function & \multicolumn{2}{|c|}{39.2027} \\
\hline
\end{tabular}

*Source: Results of primary study 
The socio-economic status is largely indicated by amalgamation of variety of variables depicting the status of the respondent in the society, of which he is a member. Socioeconomic variables employed in the present study were found negatively correlated with inefficiency. In the light of results the education level of farmer, their practical experience in farming and land under cultivation showed negative correlation with inefficiency. Moreover dummy variable for tehsils and dummy for credit also show negative results, indicating that the farmer's inefficiency will decrease if any of the above mentioned variables increase, Only the Age variable reported a positive correlation with inefficiency, indicating that young farmers were found more efficient technically in the study area, these results are shown in Table 4.

Table 4. Maximum Likelihood Estimates (Inefficiency Variables)

\begin{tabular}{|l|c|c|}
\hline Variables & Coefficient & P-values \\
\hline Constant & 1.7855 & 0.01157032 \\
\hline Farmer's age (years) & 0.0103 & 0.23025248 \\
\hline Education level of farmer (years) & $-0.0500^{* *}$ & 0.05814402 \\
\hline Farming experience (years) & -0.0353 & 0.07027384 \\
\hline Cultivated land (acres) & $-0.1274 *$ & 0.02006023 \\
\hline Dummy for Chemical Sprays & -0.7214 & 0.11982064 \\
\hline $\begin{array}{l}\text { Dummy for Any other Household } \\
\text { Income source }\end{array}$ & -0.7268 & 0.12504764 \\
\hline Dummy for Tehsil & -0.0051 & 0.48556678 \\
\hline Dummy for Credit & $-1.0242^{*}$ & 0.01888306 \\
\hline
\end{tabular}

*Source: Results of primary study

It was investigated that the efficiency scores of the borrowers of the farming area were mostly efficient as compare to the non-borrowers because non-borrowers faced financial problems to fulfill their monetary needs especially for agricultural activities. The efficiency of the borrower's farmers was estimated as 88 percent and that for nonborrowers farmers was found 76 percent, by using SFA as shown by Table 5. Farmers utilizing the credit facility were found more technically efficient. The results regarding efficiency indicated that there was 12 percent and 24 percent inefficiency in between farmers getting loans and those farmers who have not availed the facility of loan, as illustrated by Table.5. 
Table 5. Comparison of Technical Efficiency Scores between Borrowers and NonBorrowers (Wheat)

\begin{tabular}{|l|c|c|}
\hline Variables & Borrowers & Non-Borrowers \\
\hline Mean & 0.88 & 0.76 \\
\hline Minimum & 0.46 & 0.39 \\
\hline Maximum & 0.96 & 0.97 \\
\hline SD & 0.12 & 0.16 \\
\hline
\end{tabular}

*Source: Results of primary study

\section{Discussions}

The variable land cultivation time contributed positively and significantly towards the wheat production in study area. These results are in the line of results concluded by (Shafiq \& Rehman, 2000; Färe, 2013), while considering the Synthetic fertilizer and organic fertilizer, these two variables also showed positive and significant results. Elaborating that if the quantity of nitrogen, phosphorous potassium fertilizers and farm yard manure are increased there will be enhanced production of Wheat crop. Similar observations were presented by (Battese et al., 1996; Benu, 2001). The variable cultivated land contributed negative coefficient, showing a negative relationships with the technical inefficiency, indicating that farmers having large cultivated land are more technically efficient than those having less cultivated area. This result is in the line of findings of (Rahman \& Rahman, 2012).

The result of variable farming experience is found significant and negative. This result is self-explanatory, means that pertaining to increasing farming experience, in year, there will be less chances of committing mistakes in agricultural field, farmer become more efficient and consequently the production increases. Similar results were also obtained by (Huang et al., 1986) and (Lingard et al., 1983). The coefficient for variable Farmer's age was positive, pointing out to the fact that young farmers were efficient technically as compared to aged ones especially in the study region. This finding is linear with the outcome of (Parikh et al., 1995). The outcome of variable Education level of farmer was negatively related with inefficiency, meaning that higher the education level of farmers had higher technical efficiency, as noted in earlier results of Hassan and Ahmad, 2005. The dummy variable for credit, shows negative coefficient and statistically significant for the present model. According to the results the farmers availing Credit facility are found more technically efficient contrary to non-borrower farmers. This finding is again similar to that of (Giannakas et al., 2001) and (Afzal et al., 2020).

\section{Conclusion and Recommendations}

It is concluded that efficiency of borrowers and non-borrowers were different, because non-borrowers faced a lot of troubles in their agricultural activities. Borrowers easily utilized resources because they have enough money for their timely implementation of agricultural plans. Results of the study clearly show that farmers of the study area can increase their wheat production by timely use of formal loan, moreover the production of borrowers was found more as compare to that of non-borrower farmers. 
Credit can play a key role to enhance the efficiency of farmers, an easy process of granting loans both by government and private institutions, can change the whole scenario. In the light of observations it is strongly suggested that timely and easy availability of credit opportunities for deserving farmers of Chakwal district can enhance the technical efficiency of wheat growers.

\section{References}

Afzal, M.U., Mehmood, N., Tariq, S.A., Irfan, M.F. (2020). Analysis of technical efficiency of strawberry: A special case of Sheikhupura district. Journal of Agriculture and Food, 1(1), 59-68.

Ahmad, N., Sinha, D. K., \& Singh, K. M. (2018). Productivity and resource use efficiency in wheat: A stochastic production frontier approach. Economic Affairs, 63(3), 611-616.

Aigner, D., Lovell, C. K., \& Schmidt, P. (1977). Formulation and estimation of stochastic frontier production function models. Journal of econometrics, 6(1), 21-37.

Battese, G.E., Malik, S. J., \& Gill, M.A. (1996). An investigation of technical inefficiencies of production of wheat farmers in four districts of Pakistan. Journal of Agricultural Economics, 47(1-4), 37-49.

Benu, F. 2001. Farm productivity and farmers' welfare in West Timor Indonesia, Postgraduate Research Project, Muresk Institute, Australia.

Bhattacharyya, A., Bhattacharyya, A., \& Kumbhakar, S. C. (1997). Changes in economic regime and productivity growth: a study of Indian public sector banks. Journal of Comparative Economics, 25(2), 196-219.

Bozoglu, M., \& Ceyhan, V. (2007). Measuring the technical efficiency and exploring the inefficiency determinants of vegetable farms in Samsun province, Turkey. Agricultural systems, 94(3), 649-656.

Coelli, T.J. (1996). A guide to Frontier version 4.1: a computer program for stochastic frontier production and cost function estimation (Vol. 7, pp. 1-33). CEPA Working papers.

Coelli, T. J., Rao, D. S. P., O'Donnell, C. J., \& Battese, G.E. (2005). An introduction to efficiency and productivity analysis. Springer Science \& Business media.

Croppenstedt, A., Demeke, M., \& Meschi, M. M. (2003). Technology adoption in the presence of constraints: the case of fertilizer demand in Ethiopia. Review of Development Economics, 7(1), 58-70.

Eswaran, M., \& Kotwal, A. (1990). Implications of credit constraints for risk behaviour in less developed economies. Oxford Economic Papers, 42(2), 473-482.

Färe, R., Grosskopf, S., \& Lovell, C. K. (2013). The measurement of efficiency of production (Vol. 6). Springer Science \& Business Media.

Giannakas, K., Schoney, R., \& Tzouvelekas, V. (2001). Technical efficiency, technological change and output growth of wheat farms in Saskatchewan. Canadian Journal of Agricultural Economics, 49(2), 135-152.

Government of Pakistan. 2016-17. Highlights of Pakistan Economic Survey, Agriculture.

Government of Pakistan. 2019. Pakistan Economic Survey 2018-19. Finance Division, Islamabad, Pakistan. 
Hassan, S., \& Ahmad, B. (2005). Technical efficiency of wheat farmers in mixed farming system of the Punjab, Pakistan. International Journal of Agriculture and Biology, 3, 431-435.

Huang, C.J., Tang, A. M., \& Bagi, F.S. (1986). Two views of efficiency in Indian agriculture. Canadian Journal of Agricultural Economics, 34(2), 209-226.

Iqbal, M., Ahmad, M., Abbas, K., \& Mustafa, K. (2003). The impact of institutional credit on agricultural production in Pakistan [with comments]. The Pakistan Development Review, 469-485.

Iráizoz, B., Rapún, M., \& Zabaleta, I. (2003). Assessing the technical efficiency of horticultural production in Navarra, Spain. Agricultural Systems, 78(3), 387403.

Khai, H. V., \& Yabe, M. (2011). Technical efficiency analysis of rice production in Vietnam. Journal of ISSAAS, 17(1), 135-146.

Khodaverdizadeh, M., Mohammadi, M., \& Miri, D. (2019). Estimation of technical efficiency of wheat Production with emphasis on sustainable agriculture in Urmia county. Journal of Agricultural Science and Sustainable Production, 29(4), 233245.

Lambert, D. K., \& Bayda, V. V. (2005). The impacts of farm financial structure on production efficiency. Journal of Agricultural and Applied Economics, 37, 277289.

Lingard, J., Castillo, L., \& Jayasuriya, S. (1983). Comparative efficiency of rice farms in Central Luzon, the Philippines. Journal of Agricultural Economics, 34(2), 163 173.

Mamo, T., Getahun, W., Chebil, A., Tesfaye, A., Debele, T., Assefa, S., \& Solomon, T. (2018). Technical efficiency and yield gap of smallholder wheat producers in Ethiopia: A Stochastic Frontier Analysis. African Journal of Agricultural Research, 13(28), 1407-1418.

Meeusen, W., \& van Den Broeck, J. (1977). Efficiency estimation from Cobb-Douglas production functions with composed error. International economic review, 435444.

Odoemenem, I. U., \& Obinne, C. P. O. (2010). Assessing the factors influencing the utilization of improved cereal crop production technologies by small-scale farmers in Nigeria. Indian Journal of Science and technology, 3(1), 180-183.

Parikh, A., Ali, F., \& Shah, M.K. (1995). Measurement of economic efficiency in Pakistani agriculture. American Journal of Agricultural Economics, 77(3), 675-685.

Rahman, S., \& Rahman, M. (2009). Impact of land fragmentation and resource ownership on productivity and efficiency: The case of rice producers in Bangladesh. Land use policy, 26(1), 95-103.

Rosenzweig, M.R., \& Wolpin, K.I. (1993). Credit market constraints, consumption smoothing, and the accumulation of durable production assets in low-income countries: Investments in bullocks in India. Journal of political economy, 101(2), 223-244.

Shafiq, M., \& Rehman, T. (2000). The extent of resource use inefficiencies in cotton production in Pakistan's Punjab: An application of Data Envelopment Analysis. Agriculture Economics, 22(3), 321-330. 
Tavva, S., Aw-Hassan, A., Rizvi, J., \& Saharawat, Y.S. (2017). Technical efficiency of wheat farmers and options for minimizing yield gaps in Afghanistan. Outlook on Agriculture, 46(1), 13-19.

\section{Citation of Article}

Irfan, M.F., Matloob, K., Afzal, M.U., Baig, I.A. (2021). Technical Efficiency Analysis of Wheat Crop in Arid Region of Punjab, Pakistan. Journal of Agriculture and Food 2(1), 1-10. https://doi.org/10.52587/JAF010201 